\title{
Combined Infection with Cucumber green mottle mosaic virus and Pythium Species Causes Extensive Collapse in Cucumber Plants
}

Amit M. Philosoph, Department of Plant Pathology and Weed Sciences, Agricultural Research Organization, The Volcani Center, Bet Dagan 50250, Israel; and The Robert H. Smith Faculty of Agriculture, Food and Environment, The Levi Eshkol School of Agriculture, The Hebrew University of Jerusalem, Rehovot 761001, Israel; Aviv Dombrovsky and Yigal Elad, Department of Plant Pathology and Weed Sciences, Agricultural Research Organization, The Volcani Center; Amit K. Jaiswal, Department of Plant Pathology and Weed Sciences, Agricultural Research Organization, The Volcani Center; and The Robert H. Smith Faculty of Agriculture, Food and Environment, The Levi Eshkol School of Agriculture, The Hebrew University of Jerusalem; Amnon Koren, Hishtil Nurseries, Moshav Nehalim, Israel; and Oded Lachman and Omer Frenkel, ${ }^{\dagger}$ Department of Plant Pathology and Weed Sciences, Agricultural Research Organization, The Volcani Center

\begin{abstract}
In the last decade, the phenomenon of late-wilting has increased in cucumber greenhouses during Cucumber green mottle mosaic virus (CGMMV) epidemics. Because the wilting appears in defined patches accompanied by root rot, it was hypothesized that the phenomenon is caused by coinfection of soilborne pathogens and CGMMV. A field survey showed that $69 \%$ of the collapsed plants were infected with both Pythium spp. and CGMMV, whereas only 20 and $6.6 \%$ were singly infected with Pythium spp. or CGMMV, respectively. Artificial inoculations in controlled-environmental growth chambers and glasshouse experiments showed that coinfection with Pythium spinosum and

CGMMV leads to a strong synergistic wilting effect and reduces growth parameters. The synergy values of the wilting effect were not influenced by the time interval between P. spinosum and CGMMV infection. However, dry mass synergy values were decreased with longer intervals between infections. The results obtained in this study support the complexity of the wilting phenomenon described in commercial cucumber grown in protected structures during infection of Pythium spp. on the background of a vast CGMMV epidemic. They encourage a wider perspective of the complexity of agricultural diseases to apply the most suitable disease management.
\end{abstract}

Cucumber (Cucumis sativus) is one of the most common greenhouse vegetables produced worldwide (74.98 million metric tons annually) (FAO 2014). It is a warm-season plant species that grows rapidly at 24 to $29^{\circ} \mathrm{C}$. In commercial polyethylene or net-covered greenhouses or walk-in tunnels, cucumber plants are grown mostly trellised in soil, bag culture, or rockwool (McCullagh et al. 1996; Rose et al. 2003). About $70 \%$ of cucumber production in Israel is located in the central area at Hefer Valley, where they are grown as a monoculture crop, with up to three growing cycles per year. Cucumber varieties are chosen according to their suitability and performance under the climatic conditions that are expected each season.

Cucumber green mottle mosaic virus (CGMMV) was first reported in England in 1935 (Ainsworth 1935). In Israel, cucumber plants that are grown trellised in protected structures are highly affected by CGMMV (Dombrovsky et al. 2017; Reingold et al. 2016). Among the five main cucurbit-infecting tobamoviruses, CGMMV is the most economically important and it is considered a major pathogen of cucurbits worldwide (Dombrovsky et al. 2017; Gibbs et al. 2015). CGMMV belongs to the genus Tobamovirus characterized by their unique rigid morphology of rod-shaped particles, approximately $300 \mathrm{~nm}$ in length, encapsulating the viral genome of approximately 6.4-kb positive single-stranded RNA (Hollings et al. 1975; Ishibashi and Ishikawa 2016). Similar to other tobamoviruses, CGMMV forms

\section{${ }^{\dagger}$ Corresponding author: O. Frenkel; E-mail: omerf@volcani.agri.gov.il}

Contribution from the Agricultural Research Organization, The Volcani Center, Bet Dagan, Israel, number 572/17.

Funding: The research was funded by The Chief Scientist of the Ministry of Agriculture and Rural Development, Israel. Project number 1321709.

*The $\boldsymbol{e}$-Xtra logo stands for "electronic extra" and indicates that one supplementary figure is published online.

Accepted for publication 5 November 2017.

() 2018 The American Phytopathological Society highly stable particles that can persist for long periods on plant debris, in soil (Dornai et al. 1993), and on seed surfaces (Reingold et al. 2015). These particles serve as a primary source of infection for seedlings, from which the virus is later transmitted by mechanical means to surrounding plants (Broadbent 1965, 1976; Reingold et al. 2016). Postinfection, the virus spreads systemically, probably via the phloem, and may cause up to $15 \%$ yield losses in cucurbitaceous crops (Antignus et al. 1990, 2001). Recently, CGMMV outbreaks have also been reported in Canada (Ling et al. 2014), the United States (Tian et al. 2014), and Australia (Tesoriero et al. 2015).

Field surveys in commercial trellised cucumber greenhouses aimed at monitoring CGMMV spread (Reingold et al. 2016) revealed extensive collapse and growth inhibition of plants 3 to 6 weeks postplanting. Commonly, typical viral symptoms (with mosaic and mottled patterns on infected leaves) were observed on the aerial plant parts followed by extensive collapse of the plants or very poor growth performance. Similar observations have been reported since 2000 by Antignus et al. (2001), Ayo-John et al. (2014), and the Norwegian Scientific Committee for Food Safety (Sundheim et al. 2008), and for Cucumber fruit mottle mosaic virus (Antignus et al. 2005). The wilting that leads to plant collapse appears mostly in defined patches in greenhouses and is often accompanied by damage to the lower plant organ tissues, resembling symptoms from soilborne fungal or oomycete pathogens. In many climatic areas, soilborne pathogens are considered a major problem in greenhouse cucumber (Lamichhane et al. 2017). The main diseases include Fusarium crown rot, Fusarium wilt (Lievens et al. 2007), and Pythium damping-off and root rot. Pythium spp. are considered a major pathogen of cucumber (Ben-Yephet and Nelson 1999; Zitter et al. 1996), potentially causing up to $75 \%$ mortality in young seedlings (Al-Sa'di et al. 2007, 2008). Pythium spp. usually survive between seasons as oospores for periods of more than 12 months (Martin and Loper 1999). However, Pythium damage is not restricted to young seedlings; the pathogen often affects mature plants, with infection of taproots, root tips, or feeder roots, limiting plant vigor and yield, and sometimes causing death at later stages (McCullagh et al. 1996; Van der Plaats-Niterink 1981).

Interactions between viral and soilborne oomycetes or fungal pathogens have been documented in several pathosystems, resulting in increased damage, such as cucumber coinfected with Cucumber 
mosaic virus (genus Cucumovirus) and Pythium ultimum (Nitzany 1966) or Rhizoctonia solani (Bateman 1961), pea coinfected with Fusarium pea rot (Fusarium solani f. sp. pisi) and Bean yellow mosaic virus (Beute and Lockwood 1968), and maize coinfected with Maize dwarf mosaic virus and corn root rot (Tu and Ford 1971).

Because brownish deep cracks or fissures in crowns, darkened roots, and constrained growth (typical symptoms of soilborne pathogens) were commonly observed, we hypothesized that Pythium spp. play an important role in causing extensive damage during CGMMV epidemics, and that the damage from the coinfection results from a synergistic reaction of disease symptoms and severity. The specific goals of this research were to (i) identify the pathogens involved in cucumber collapse in commercial plots during CGMMV epidemics, (ii) quantify the effect of combined infection (CGMMV and Pythium spp.) on cucumber health, and (iii) study the effect of the infection order and time interval between Pythium spp. and CGMMV inoculations on cucumber health.

\section{Materials and Methods}

Data collection and pathogen isolates. Between January 2014 and January 2016, 16 sampling visits were made to commercial cucumber greenhouses in the central Hefer Valley (Ahituv, geographical coordinates 32.389988, 34.990965). In each greenhouse, foci with collapsed cucumber plants that were more than 3 weeks postplanting were located. In each focus, a combination of collapsed plants and standing plants within a radius of less than $1.5 \mathrm{~m}$ from the collapsed plants was collected. In total, 188 plants were evaluated. Each plant was assessed and classified visually into three different symptom categories: (i) collapsed plants or very poor growth performance $(n=75)$, (ii) plants with viral symptoms resembling CGMMV (green mottle and condensed growth, $n=60$ ), or (iii) standing plants with none of these symptoms $(n=53)$. In each symptom group, all plants were examined for the presence of Pythium spp. using selective corn meal agar (CMA), as described in the next section, along with enzyme-linked immunosorbent assay (ELISA) (Clark and Adams 1977) for the presence of CGMMV coat protein. Commercial CGMMV antibodies diluted 1:1000 (Agdia) were used as previously described by Shargil et al. (2016). Isolation and detection were also performed for Fusarium crown rot (F. oxysporum f. sp. radicis cucumerinum [FORC]) on Nash and Snyder Fusariumselective medium (Nash and Snyder 1962) and by reverse-transcription polymerase chain reaction (PCR) for Cucurbit yellow stunting disorder virus (CYSDV) detection (Rubio et al. 1999) to disqualify a significant interaction of CYSDV or FORC, respectively in the pathosystem. Within each of the three visual symptom groups (i.e., collapsed plants or extreme growth retardation, plants with viral symptoms resembling CGMMV, and standing plants with none of these symptoms), the statistical differences between the proportions of diagnosed coinfected plants (i.e., CGMMV + Pythium) were compared with the proportions of the other infections (plants with Pythium spp. alone, plants with CGMMV alone, or plants with neither of these) by $\chi^{2}$ test $(\alpha=0.05)$.

Isolation and characterization of the pathogens. Root and crown tissue of each collected plant was washed with sterile distilled water and sterilized with $1 \%$ hypochlorite for $1 \mathrm{~min}$. Each sample was positioned on Pythium selective medium based on CMA (CMA at $17 \mathrm{~g} /$ liter [Difco Laboratories], agar at $10 \mathrm{~g} /$ liter, $0.1 \mathrm{~g}$ of nystatin, $0.1 \mathrm{~g}$ of penicillin, $0.05 \mathrm{~g}$ of vancomycin, and $0.05 \mathrm{~g}$ of pentachloronitrobenzene). In addition, all samples were tested on Nash and Snyder agar and potato dextrose agar (PDA; Difco Laboratories) with chloramphenicol at $250 \mathrm{mg} /$ liter. Because Pythium spp. were by far the most abundant pathogen, 30 randomly selected isolates were transferred to PDA medium with no chloramphenicol and tissue was collected into crush tubes with two 0.5 -cm-diameter tungsten balls. DNA was extracted from ground mycelium with the commercial kit MasterPure yeast DNA (Epicenter) according to the manufacturer's protocol, with one modification: tissue was crushed with lysis buffer in a Geno/ Grinder (SPEX SamplePrep 2012) homogenization machine at $6,000 \mathrm{rpm}$ for $60 \mathrm{~s}$ instead of the recommended liquid nitrogen grinding. DNA concentration was determined in an ND-1000 spectrophotometer (NanoDrop Technologies) and adjusted to $20 \mathrm{ng} / \mu \mathrm{l}$ for PCR. Primers internal transcribed spacer (ITS)1 and ITS4 were used to amplify the ITS1-5.8S-ITS2 region following the protocol by White et al. (1990); the sequences of the 30 isolates were compared with the National Center for Biotechnology Information database and representative isolates were deposited in GenBank under accession numbers MF116303 and MF118618. Leaves and petioles from each plant were collected for CGMMV detection by ELISA, as described above.

Plant growing conditions. Cucumber seed (C. sativus 'Kfir') were sown in a nursery tray containing potting mixture in pest- and diseasefree controlled-environmental growth chambers at $23 \pm 1^{\circ} \mathrm{C}$. The germinated seedlings were kept under a 12-h photoperiod, and were fertilized and irrigated with drippers twice a day (approximately 0.1 liter per irrigation) with 5:3:8 N-P-K fertilizer (irrigation water was planned to have total N, P, and K concentrations of 120, 30, and $150 \mathrm{mg} /$ liter, respectively; EC $2.2 \mathrm{dS} / \mathrm{m}$ ), allowing for 25 to $50 \%$ drainage.

Pathogen growth and inoculation. $P$. spinosum isolate PS-01 was cultured on PDA and incubated at $25^{\circ} \mathrm{C}$ for 2 days. Ten populated agar disks $(10 \mathrm{~mm})$ were excised from the 48 -h-old colony edge and placed in a 500-ml Erlenmeyer flask containing $80 \mathrm{~g}$ of autoclaved pearl millet. The culture was incubated for 6 days at $25^{\circ} \mathrm{C}$. $P$. spinosum-colonized millet seed were homogenized in a Waring blender (Moulinex) for $30 \mathrm{~s}$ and adjusted to $0.25 \%$ (wt/wt) with the potting mixture. The control treatment consisted of a mix of $0.25 \%$ noncolonized seed. CGMMV inoculation was conducted as previously described (Reingold et al. 2015). Briefly, cucumber plants were mechanically inoculated with extract from CGMMV-infected plants (Ah isolate, GenBank accession number KF155232) that were homogenized in phosphate buffer $(0.01 \mathrm{M}, \mathrm{pH} 7)$ containing carborundum dust (silicon carbide).

Controlled-environment experiments. Plant seedlings were grown before inoculation as described above until 6 days after sowing. Four uniform cucumber seedlings were transplanted to each 3-liter pot $(16 \mathrm{~cm}$ in diameter) containing potting mixture (peat/tuff, 7:3 [vol/vol]; Shaham Givat Ada). Treatments (four pots per treatment, for a total 16 plants) consisted of (i) pathogen-free, (ii) inoculation with $P$. spinosum, (iii) inoculation with CGMMV, and (iv) inoculation with both CGMMV and $P$. spinosum, as described above. The percentage of collapsed transplants per replicate was recorded from 2 to 11 days until disease progression ceased (up to 40 days after transplanting). Collapsed plant records were used to draw disease progress curves and calculate the area under the mortality progress curve (AUMPC, in percentage $\times$ days), representing the intensity of the entire epidemic in each treatment. AUMPC was determined as previously described (Jaiswal et al. 2014). The experiments were conducted twice.

Glasshouse experiments. Because the controlled-environment growth chamber experiments could not be used to assess plant growth parameters, study the infection process in more mature plants, or study the pathosystem under naturally fluctuating daily temperatures, a set of four consecutive experiments were conducted in a glasshouse. Healthy 6-day-old-seedlings were transplanted into $32 P$. spinosum-inoculated or 32 noninoculated 3-liter pots (four plants in each pot) for 30 days. After mortality ceased, the surviving standing plants were transferred to a glasshouse for $48 \mathrm{~h}$. The number of plants per pot was reduced to 1 plant in each pot, and the pots were divided into four treatments of 16 plants each as follows: (i) pathogen-free, (ii) inoculation with $P$. spinosum, (iii) inoculation with CGMMV, or (iv) inoculation with both CGMMV and $P$. spinosum. To ensure that the plants in treatments iii and iv harbored $P$. spinosum, five plant roots from each treatment were tested for Pythium's presence as described above and five plants from the noninoculated plants were tested as a control. Plants were grown under irrigation (twice daily) of approximately 0.8 liter/day for an additional 30 days. Plant collapse was evaluated every 4 to 9 days and cucumber dry mass weight was evaluated at the end of the experiments (30 days post-CGMMV inoculation). Plant shoots were dried in an air-circulating $60^{\circ} \mathrm{C}$ oven for 14 days until the dry weight stabilized. The experiment was conducted four times.

Effects of infection chronology and time interval between $P$. spinosum and CGMMV infection on cucumber health. The influence of infection chronology and interval between infection with $P$. spinosum and the viral pathogen CGMMV was evaluated in controlled-environment growth chambers. Six days after sowing, 
seedlings were transplanted into $P$. spinosum-inoculated media or noninoculated media, considered infection day 0 . Every 2 days (day $0,2,4$, 6 , and 8 after $P$. spinosum inoculation), four $P$. spinosum-inoculated pots and four noninoculated pots ( $n=16$ plants for each treatment) were infected with CGMMV. To study the effect of CGMMV infection before $P$. spinosum inoculation, 4 days after sowing (i.e., 2 days before $P$. spinosum inoculation, or day -2 ), 32 seedlings were inoculated with CGMMV, and 16 of them were inoculated 2 days later with $P$. spinosum. The third treatment included 16 seedlings inoculated with $P$. spinosum with no CGMMV inoculation and another 16 seedlings that served as a noninoculated control. During the first 4 days after $P$. spinosum infection, seedling mortality with and without CGMMV infection was high, reaching 18 to $32 \%$ (before the stabilization that occurred on day 4). Therefore, it was not possible to distinguish between seedling mortality from $P$. spinosum alone or from the combined infection. Hence, our results only relate to the mortality rate (MR) from 4 days post-Pythium inoculation onward. We took this approach only after comparing the MR from the Pythium-only treatment and the coinfection treatments during the 4 days prior to stabilization by $t$ test. Because no differences were found between the Pythium treatment group and any of the combined-infection treatment groups until day 4 , we postulated that, during these first 4 days, plant collapse is due to Pythium alone. Plant mortality was documented at 2- to 8-day intervals until day 35 ; then, the stems and leaves were collected into paper bags and placed in a $60^{\circ} \mathrm{C}$ dry oven for dry mass measurement. The experiment was conducted twice.

Synergistic effect of CGMMV and $P$. spinosum on plant disease and plant growth parameters. The effect of coinfection with CGMMV and $P$. spinosum on the relative AUMPC values of cucumber was estimated by using the Abbott formula (Kosman and Cohen 1996; Levy et al. 1986). The expected MR (MRexp) was calculated as follows: MRexp $=a+b-a \times b / 100$ and SF $=$ MRobs/MRexp, where $a=$ MR caused by one pathogen ( $P$. spinosum or CGMMV) when applied alone, $b=$ MR caused by the other pathogen when applied alone, MRexp = expected MR when the two pathogens were applied together, MRobs = observed MR when the two pathogens were applied together, and SF = the synergy factor achieved by the integration of the two pathogens. When $\mathrm{SF}=1$, the interaction between the pathogens is additive; when $\mathrm{SF}<1$, the interaction is antagonistic, and when SF $>1$, the interaction is synergistic (Kosman and Cohen 1996; Levy et al. 1986). The SF was calculated similarly for plant growth parameters, including height and dry mass.

Statistical analysis. The greenhouse and infection chronology experiments were conducted twice and the glasshouse experiments were conducted four times. In each experimental set, the results of the experimental repeats were pooled and analyzed jointly, with "experiment" as an additional blocking factor. Data were analyzed by one-way analysis of variance (ANOVA) using JMP 12 software (SAS Institute). To enable ANOVA, percentage values were normalized by arcsine squareroot transformation. Multiple comparisons of the means were conducted using the Tukey-Kramer honestly significant difference test $(\alpha=0.05)$.

\section{Results}

Data collection and pathogen isolates. In total, 188 plants were collected in designated foci around collapsed areas. Analysis of the most common cucumber soilborne pathogens identified them as Pythium spp. From the 30 sequenced isolates, 20 isolates had 99.1\% ITS sequence identity to the reference isolate of $P$. spinosum (GenBank accession number AY598701.2) and the other 10 isolates had $99.1 \%$ sequence identity to $P$. aphanidermatum (GenBank accession number AY598622.2), (LéVesque and De Cock 2004). ELISA was positive for CGMMV in the tissue of 119 plants.

Of the 75 collapsed plants, $69.3 \%$ were positive for both CGMMV and Pythium, whereas only $20 \%$ were positive for Pythium alone, $6.7 \%$ were positive for CGMMV alone, and $4.0 \%$ were negative for CGMMV and Pythium (Fig. 1A). The differences between the damping-off proportions of the coinfected plants were significantly higher than those of all other treatments $(P<0.001)$.

Among the 113 standing plants within infected foci, in symptomless plants $(n=53)$, only $3.7 \%$ were coinfested with both pathogens, whereas $52.8 \%$ were infested with Pythium alone. CGMMV was present in $9.4 \%$ of the plants and $34 \%$ harbored neither pathogen (Fig. 1B).

Of the 60 plants with CGMMV-like symptoms, $60 \%$ were infected with CGMMV alone and $31.6 \%$ were coinfected with CGMMV and Pythium (total of $91.6 \%$ with CGMMV). Among the rest, $1.6 \%$ included Pythium with no detection of CGMMV (but with positive detection of CYSDV) and $6.6 \%$ with no detection of either pathogen (i.e., CGMMV or Pythium) but with positive detection of CYSDV (Fig. 1C).
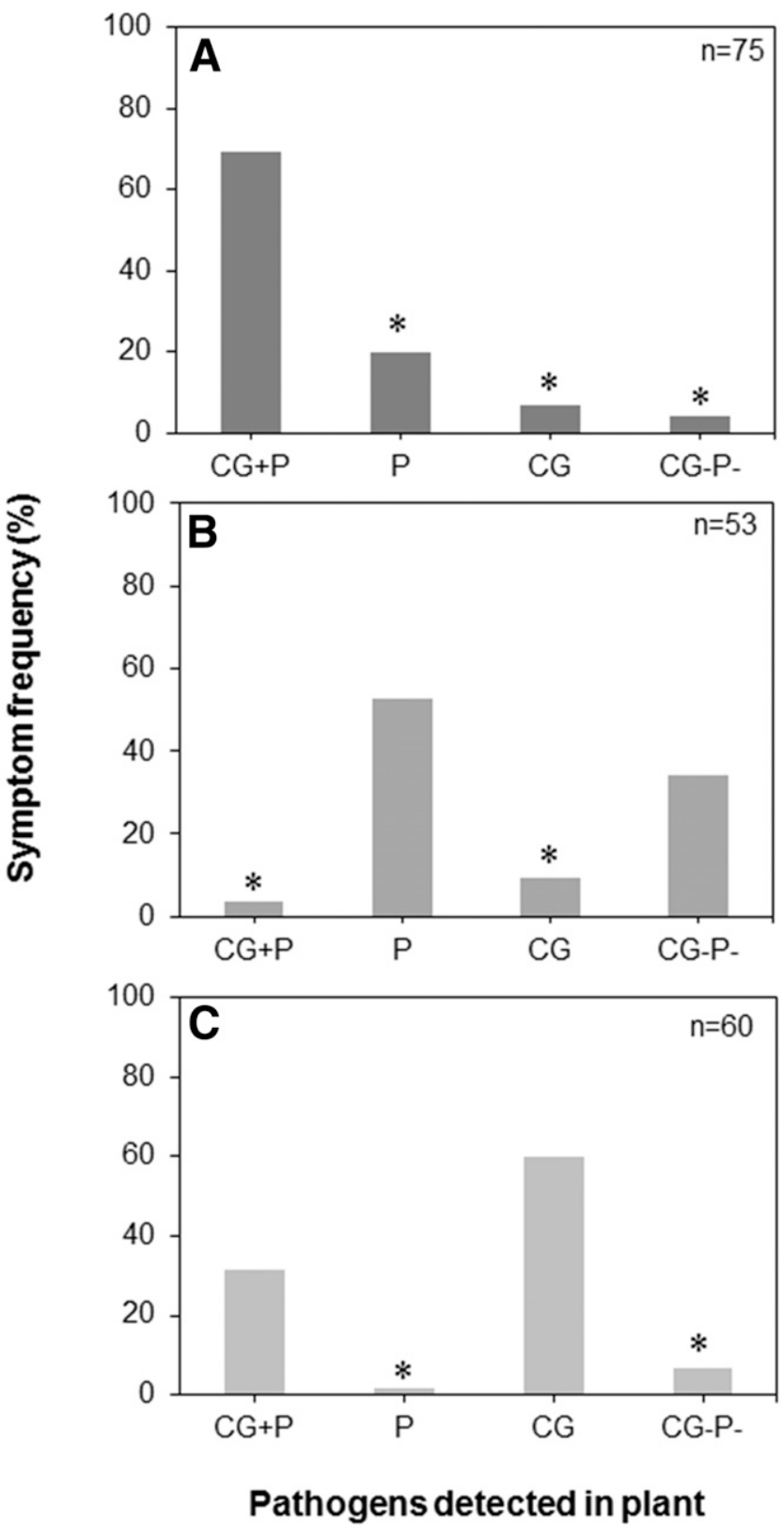

Fig. 1. A-C, Symptom frequency of pathogens in cucumber plants within each of three symptom categories. $\mathrm{CG}+\mathrm{P}$, coinfection with Pythium spp. and Cucumber green mottle mosaic virus (CGMMV); $P$, infection with Pythium spp.; CG, infection with CGMMV; and CG-P-, negatively detected for CGMMV and Pythium spp. 1A = collapsed plants, $1 \mathrm{~B}=$ standing plants without symptoms, and $1 \mathrm{C}=$ standing plants with CGMMV-like symptoms. Plants collected more than 3 weeks after planting from commercial plots were visually divided into the three symptom categories and each plant was tested for presence of the pathogen on potato dextrose agar and by enzyme-linked immunosorbent assay. Asterisk represents significant differences $(\alpha=0.05)$ between $\mathbf{A}$, frequency of coinfected plants and those infected with each pathogen alone; B, frequency of plants negatively detected for CGMMV or Pythium spp. and each of the other treatments; and $\mathbf{C}$, frequency of plants inoculated with CGMMV alone and each of the other treatments, by $\chi^{2}$ test. 
FORC was occasionally detected as a pathogen. However, FORC and CGMMV coinfection was only isolated in $17.8 \%$ of the 75 collapsed plants. Furthermore, collapsed plants that involved FORC and CGMMV coinfection were mostly restricted to the spring or earlysummer sampling dates ( 8 of 40 collapsed plants [20\%]) whereas, during the other seasons, it was only detected in 2 of 35 collapsed plants $(5.7 \%)$. Therefore, FORC confections could not explain any of the collapse documented during the other growing seasons.

Controlled-environment experiments. Mortality of young seedlings infected with $P$. spinosum alone or simultaneously coinfected with CGMMV was most intense 48 to $96 \mathrm{~h}$ postinfection, reaching 28.8 and $35.7 \%$, respectively, after 4 days, with no significant differences between the treatments during day 2 and day 4 evaluations ( $P=$ 0.35 and 0.49 , respectively). However, whereas collapse due to Pythium infection nearly leveled out after 8 days (30.7\%), collapse in the coinfection treatment continued to rise, reaching a significantly higher MR (67.8\%) at the end of the experiment $(P=0.002)$ (Fig. 2). The AUMPC values of the two treatments showed similar patterns but the value for the $P$. spinosum-infected plants was significantly lower than that for the coinfection treatment $(839 \pm 227$ and 1,994 \pm 319 , respectively; $P=0.006$ ). The first apparent symptoms of CGMMV were detected in the leaf tissue 12 to 14 days post-CGMMV infection regardless of the presence or absence of $P$. spinosum. Nevertheless, no mortality was observed for the treatment with CGMMV infection alone or for the noninoculated control (Fig. 2). The SF value of the coinfection treatment conducted for final MR on day 40 was 2.21 .

Glasshouse experiment. Plant mortalities in the glasshouse experiments started 4 days after the coinfection treatment, reaching $38.2 \%$ after 10 days (and $40.8 \%$ after 30 days) (Fig. 3). The first collapse of singly $P$. spinosum-infected plants started 7 days postinfection, reaching a plateau at a significantly lower infection rate $(17.9 \%)$ after 14 days. Initial CGMMV symptoms were first observed 12 to 14 days post-CGMMV infection but MR were minor for the CGMMV-infected plants: the first plant collapsed only 30 days after infection, reaching a final MR of 5.43\% (Fig. 3). No plant mortality was observed for the noninoculated control treatment. The AUMPC values of the three treatments showed a similar pattern. Coinfection treatment reached $963.9 \pm 240.2$ and was significantly higher than the separate $P$. spinosum and CGMMV treatments at $394.4 \pm$ $136.4(P=0.03)$ and $24.4 \pm 13.4(P=0.035)$, respectively. The synergistic effect of the coinfection treatment were 1.82 and 2.98 for the final MR on day 30 and for AUMPC values, respectively. Coinfection treatments also influenced plant growth parameters. Plant dry mass of the coinfected plants was significantly lower than those from

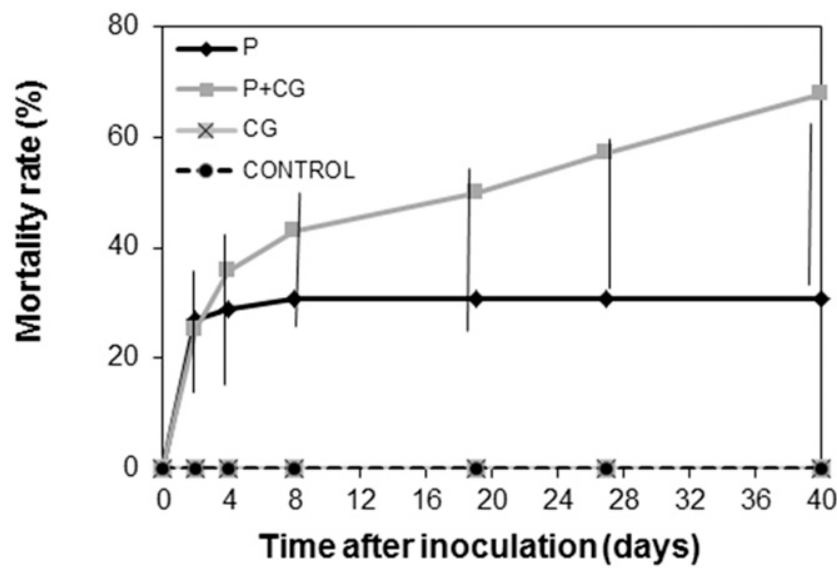

Fig. 2. Disease progress curve of cucumber mortality upon inoculation with Pythium spinosum alone $(P)$, Cucumber green mottle mosaic virus alone (CG), both $P$. spinosum and Cucumber green mottle mosaic virus (CGMMV) on the same day $(\mathrm{P}+\mathrm{CG})$, or no pathogens (CONTROL). Plants were grown in potting mixture and maintained in environmentally controlled chambers at $23 \pm 1^{\circ} \mathrm{C}$ after inoculation. Six-day-old seedlings were inoculated with Pythium spp. and CGMMV on day 0. Vertical lines represent least significant differences obtained from Tukey's honestly significant difference test $(\alpha=0.05)$. all other treatments (Fig. 4), with a synergy value of 1.302. The $P$. spinosum-inoculated plant biomass was significantly higher than that of the coinfected treatment $(P<0.001)$ but significantly lower than that of the CGMMV and control treatments $(P=0.014$ and $P<0.0001$, respectively) (Fig. 4).

Effects of infection chronology and time interval between $P$. spinosum and CGMMV infection on cucumber health. Seedling mortality in $P$. spinosum-infected treatments started 2 days after infection and reached a plateau of $28 \%$ on day 4 after infection. During these 4 days, no significant differences were detected between any of the coinfection treatments (days $-2,0$, and 2 relative to CGMMV inoculation day [CGid]), where disease mortality ranged between 18.8 and $31.3 \%(P>0.35)$. In addition, during these 4 days, no significant differences were detected between the MR for the coinfection

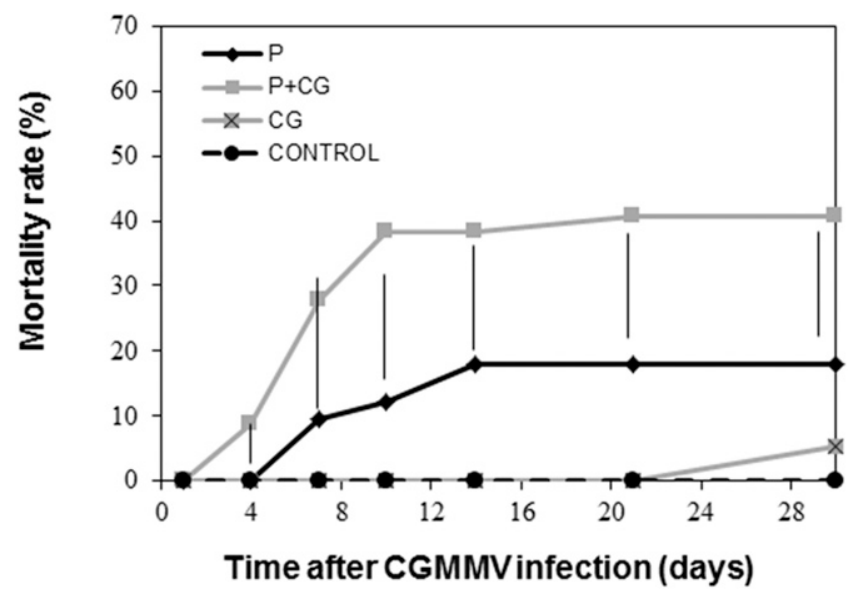

Fig. 3. Disease progress curve of cucumber mortality upon inoculation with Pythium spinosum alone (P), Cucumber green mottle mosaic virus (CGMMV) alone (CG), both Pythium spinosum and CGMMV $(\mathrm{P}+\mathrm{CG})$, or no pathogens (CONTROL). Plants were grown in potting mixture and maintained in environmentally controlled chambers at $23 \pm 1{ }^{\circ} \mathrm{C}$. Six-day-old seedlings were inoculated with Pythium spp. and maintained for 30 days, after which plants were removed to noncontrolled glasshouses and CG and $P+C G$ groups were infected with CGMMV after 4 days. Vertical bars represent least significant differences obtained from Tukey's honestly significant difference test $(\alpha=0.05)$.

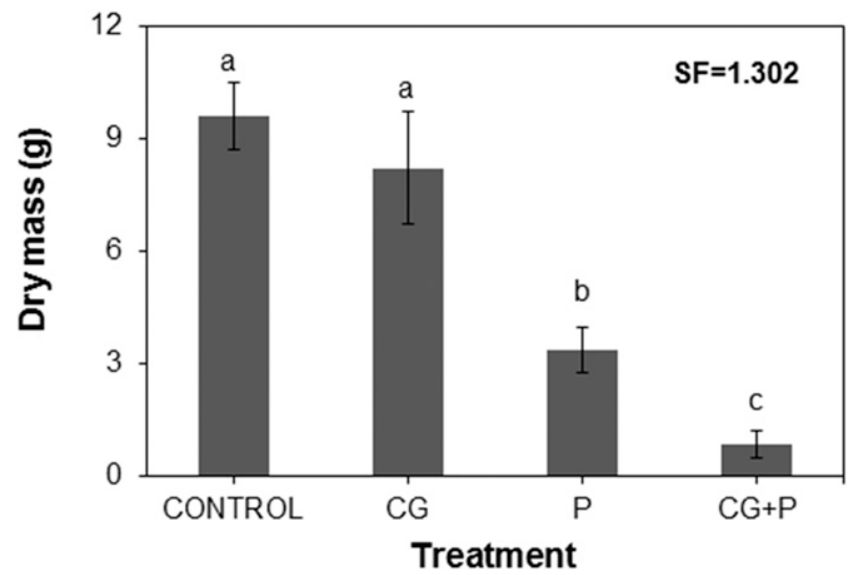

Fig. 4. Dry mass of cucumber plants from different treatment groups. CONTROL = pathogen-free, $C G=$ infected with Cucumber green mottle mosaic virus (CGMMV) alone, $\mathrm{P}=$ infected with Pythium spinosum alone, and $\mathrm{CG}+\mathrm{P}=$ infected with Pythium spinosum and CGMMV. Plants were grown in potting mixture and maintained in environmentally controlled chambers at $23 \pm 1^{\circ} \mathrm{C}$. Six-day-old seedlings were inoculated with Pythium spp. and maintained for 30 days, after which plants were removed to noncontrolled glasshouses and the $C G$ and $C G+P$ groups were infected with CGMMV after 4 days. Plants were grown for an additional 30 days and then aboveground parts were collected and dried at $60^{\circ} \mathrm{C}$. Vertical bars represent standard error. Different letters represent significant differences obtained from Tukey's honestly significant difference test $(\alpha=0.05)$. SF $=$ synergy factor of combined infection, as described by Levy et al. (1986) for the Abbott formula. 
treatment and treatment with $P$. spinosum alone, indicating that coinfection with CGMMV and $P$. spinosum did not affect the MR during the first 4 days of infection.

After the initial stage (until day 4), no collapsed plants were detected for the control or CGMMV-infected plants, and the P. spinosuminfected plants reached only $3.13 \%$ mortality (Fig. 5). However, all of the coinfected plants continued to collapse, reaching final MR of between $21.6 \%$ for 6 CGid and $48.95 \%$ for 2 CGid (Fig. 5). All relative AUMPC values were calculated and showed high synergy values for the coinfection treatments (Fig. 6). The synergistic effect on 2 CGid was significantly higher than on 6 CGid or 8 CGid. Nevertheless, no significant correlation $\left(r^{2}=0.531, P=0.32\right)$ was found between the CGid and synergy values of the relative AUMPC (Fig. 6). The dry mass values were also influenced by the coinfection (Supplementary Fig. S1) and all CGid treatments had an SF > 1, except for the 8 CGid treatment. A significant correlation $\left(r^{2}=0.96, P<0.0001\right)$ was detected between CGid and the synergy value of the dry mass, the latter decreasing with time (Fig. 7).

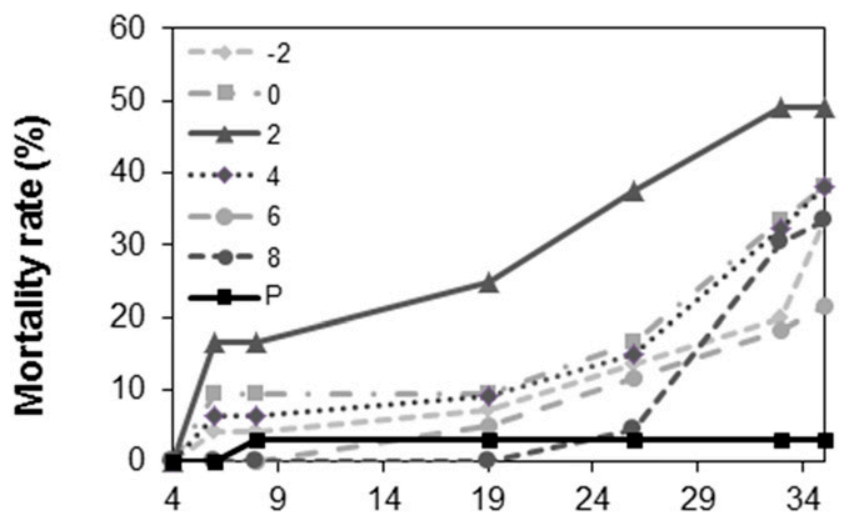

Time after Pythium inoculation (days)

Fig. 5. Disease progress curve of cucumber mortality for plants inoculated with Pythium spinosum and Cucumber green mottle mosaic virus (CGMMV) on different days. CGMMV was inoculated as follows: 2 days before inoculation with $P$. spinosum $(-2)$, on the same day as $P$. spinosum inoculation (0), and 2 days (2), 4 days (4), 6 days (6), and 8 days (8) after inoculation with $P$. spinosum; the control consisted of $P$. spinosum inoculation only $(P)$. Mortality data curve is presented from 4 days after Pythium inoculation until day 35. No mortality was observed for the noninoculated control or for seedlings inoculated with CGMMV. Plants were grown in potting mixture and maintained at $23 \pm 1^{\circ} \mathrm{C}$ after inoculation.

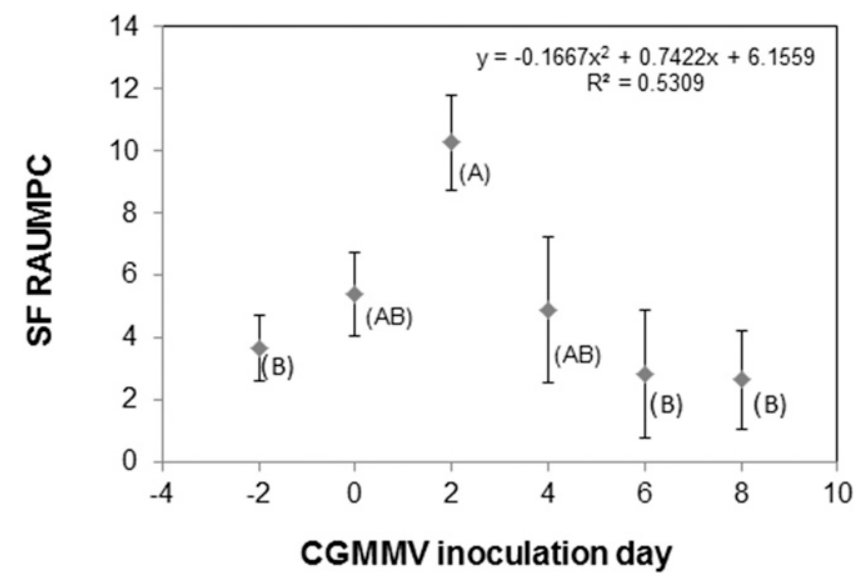

Fig. 6. Correlation between Cucumber green mottle mosaic virus (CGMMV) inoculation day and synergy factor (SF) based on the relative area under the mortality progress curve (RAUMPC) values for the combined infection with CGMMV and Pythium spinosum. SF value was calculated as described by Levy et al. (1986) for the Abbott formula. Vertical lines represent standard error. Different letters represent significant differences obtained from Tukey's honestly significant difference test $(\alpha=0.05)$.

\section{Discussion}

Monoculture has become dominant in modern agriculture, contributing to growers' crop specialization and market reputation. However, from a phytopathological point of view, the byproduct of monoculture is the continuous exposure of crops to a range of pathogens that, in time, can build up sufficient inoculum that is preserved in the soil between the repetitive crop growing cycles (Katan 2010).

For more than a century, virus species belonging to the genus Tobamovirus have been considered a major threat to agriculture worldwide. In cucumber, the primary CGMMV inoculum spreads to neighboring plants by mechanical contact during trellising and pruning that is performed 12 to 21 days postplanting and later, following continuous harvesting during the growing cycle (Dombrovsky et al. 2017; Reingold et al. 2016). The damage caused by CGMMV affects plant growth parameters, along with typical mosaic and mottling on leaves and fruit. Wilting has also been documented in several countries associated with CGMMV symptoms under high temperatures, due to high titers of viral particles in the xylem leading to partial inhibition of water transfer to the upper plant tissues (Antignus et al. 1990, 2001; Reingold et al. 2016; Sundheim et al. 2008). Nevertheless, in our experiments, we were barely able to induce plant collapse with CGMMV alone under various environmental conditions.

Similarly, Pythium disease in cucumber (and other greenhouse crops) is mostly considered a seedling disease that causes significant damage during the first weeks after planting (Hendrix and Campbell 1973; Herrero et al. 2003). Farmers often apply a systemic fungicide such as metalaxyl $\left(\mathrm{C}_{10} \mathrm{H}_{21} \mathrm{NO}_{4}\right)$ or propamocarb $\left(\mathrm{C}_{9} \mathrm{H}_{20} \mathrm{O}_{2}\right)$ following planting in order to avoid wilting of seedlings during the first weeks (Postma et al. 2000). In general, older cucumber plants that have survived the first stage of early collapse will continue to host Pythium spp. in their tissues with only relatively minor disease symptoms or mild effects on plant performance from an agricultural perspective (Cherif et al. 1994). However, cucumber collapse at later growing stages ( $>30$ days postplanting) has also been documented, occasionally accompanied by additional environmental stresses such as salinity (Al-Sadi et al. 2010) and other pathogens (Koike and Yang 1971; Nitzany 1966).

The results obtained in this study support the complexity of the plant collapse phenomenon described in commercial cucumber grown in protected structures. The combined infection of Pythium spp. on the background of major CGMMV epidemics in most cucumber-growing areas results in a synergistic effect that is reflected in higher MR and increased damage in terms of plant growth parameters. We conducted experiments to provide a clear explanation for cucumber plant collapse, which was found to reflect the plant's response to this coinfection. Our results indicated a synergistic effect between CGMMV and Pythium infections.

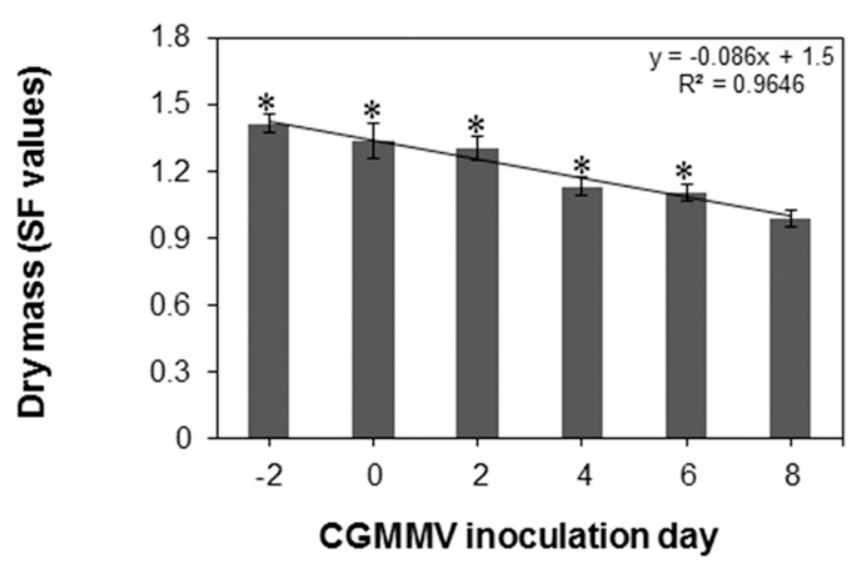

Fig. 7. Correlation between Cucumber green mottle mosaic virus (CGMMV) inoculation day and the synergy factor (SF) values for the dry mass weight of plants with combined infection with CGMMV and Pythium spinosum. After 35 days, plant biomass was collected and dried at $60^{\circ} \mathrm{C}$. SF value was calculated as described by Levy et al. (1986) for the Abbott formula. Vertical lines represent standard error. Asterisks represent SF values significantly higher than $1(\alpha=0.05)$. 
It should be noted that other soilborne pathogens and biotic stresses cannot be ruled out as possible biotic pressure that might contribute to the plant-collapse phenomenon (e.g., FORC). The fact that CGMMV and Pythium spp. are much more common during all growing seasons, whereas FORC is only common during the spring or early-summer growing stage, led us to determine that Pythium spp. and CGMMV are more significant causal agents; the exact role of FORC and other soilborne pathogens warrants a separate study during the spring season.

Our controlled-environment experiments showed the biphasal character of the epidemic. Pythium spp. alone caused mortality mostly during the first week after infection, before mortality ceased. The second stage of collapse started about 10 days after the CGMMV infection, indicating the importance of the coinfection to the synergistic collapse stage (Fig. 2).

The major impact of this study is to encourage a wider perspective on the complexity of agricultural diseases in order to apply the most suitable disease management. The results indicate the need for a proper dual-management strategy that first aims to reduce the primary CGMMV infection in the soil; CGMMV-infected plants should be removed (with appropriate sanitation measures) before intensive plant mechanical handling (e.g., trellising, pruning, and harvesting) to initiate inoculum decline in the growing area (Dombrovsky et al. 2017; Reingold et al. 2016). In addition, the significant correlation between viral infection date and the synergistic effect in terms of plant growth parameters (Fig. 7) implies that postponing CGMMV infection may contribute to a reduction in plant growth during the coinfection. Nevertheless the synergistic effect on mortality was not influenced by the time interval between Pythium inoculation and CGMMV inoculation days (Figs. 3 and 5). As a result, it might be advisable to try to approach the system by applying anti-Pythium treatments (chemical or biological) in order to suppress the damage in the field. Lamichhane and Venturi (2015) also suggested that the appearance of a second pathogen should be incorporated into simulation models and disease-forecasting packages to improve their results.

In recent years, the important role of multispecies interactions in the wild and in agroecosystems has been recognized (Lamichhane and Venturi 2015; Tollenaere et al. 2017). Coinfection with different pathogens may result in diverse epidemiological outcomes, including antagonism and synergism (Ataga et al. 1999; Tollenaere et al. 2017). The most studied interactions consist of synergistic damage to the plant host caused by coinfections within the kingdom of the pathogen (Le May et al. 2009; Murphy and Bowen 2006), as well as crosskingdom interactions (Ito et al. 2017; Lakshman et al. 2017; Tollenaere et al. 2017). However, there are still major knowledge gaps regarding the mechanisms leading to the increased disease severity. The combination of soilborne pathogens with tobamoviruses such as Pythium spp. with CGMMV has been little studied, and the limited data are mostly constrained to the purely molecular aspects of the Tobacco mosaic virus $-F$. oxysporum f. sp. lycopersici system (Andolfo et al. 2014). New Tobamovirus species that are capable of overcoming crop-resistance genes seem to be associated with constantly increasing damage on a large agricultural scale (Fillmer et al. 2015; Luria et al. 2017; Salem et al. 2016). It is important to understand the main mechanisms that might be involved in the phenomenon. One possible clue to the wilting that occurs during the viral-oomycete coinfection was addressed by Fletcher et al. (1969), who found a 50\% weight reduction in the root system of CGMMV-infected plants; this, in collaboration with Pythium damage, might cause fatal damage to the root system from which the plant cannot recover. An additional explanation might be the fact that CGMMV clogs the vessel system of the plant (Reingold et al. 2016), while additional stress on the root and collar region by Pythium infection can also explain the wilting effect. Another possibility that should be addressed is that each of the pathogens have a different impact on the plant defense mechanisms, with possible antagonistic effects between defense systems (Glazebrook 2001) and poor defense performance when more than one pathogen attacks the plant host (Vos et al. 2013). A deeper understanding of these little-studied mechanisms may provide additional solutions for the problem of coinfection.

\section{Acknowledgments}

We thank D. Shtienberg for his valuable advice and F. Abu-Moch, N. Mor, and

S. Peretz for their valuable assistance in the field.

\section{Literature Cited}

Ainsworth, G. C. 1935. Mosaic disease of cucumber. Ann. Appl. Biol. 22:55-67. Al-Sadi, A. M., Al-Masoudi, R. S., Al-Habsi, N., Al-Said, F. A., Al-Rawahy, S. A., Ahmed, M., and Deadman, M. L. 2010. Effect of salinity on Pythium dampingoff of cucumber and on the tolerance of Pythium aphanidermatum. Plant Pathol. 59:112-120.

Al-Sa'di, A. M., Drenth, A., Deadman, M. L., Al-Said, F. A., Khan, I., and Aitken, E. A. B. 2008. Potential sources of Pythium inoculum into greenhouse soils with no previous history of cultivation. J. Phytopathol. 156:502-505.

Al-Sa'di, A. M., Drenth, A., Deadman, M. L., De Cock, A., and Aitken, E. A. B 2007. Molecular characterization and pathogenicity of Pythium species associated with damping-off in greenhouse cucumber (Cucumis sativus) in Oman. Plant Pathol. 56:140-149.

Andolfo, G., Ferriello, F., Tardella, L., Ferrarini, A., Sigillo, L., Frusciante, L., and Ercolano, M. R. 2014. Tomato genome-wide transcriptional responses to fusarium wilt and Tomato mosaic virus. PLoS One 9:e94963.

Antignus, Y., Lachman, O., Pearlsman, M., and Koren, A. 2005. Note: Containment of Cucumber fruit mottle mosaic virus (CFMMV) infection through roots by planting into a virus-free intermediating medium. Phytoparasitica 33 85-87.

Antignus, Y., Pearlsman, M., Ben-Yoseph, R., and Cohen, S. 1990. Occurrence of a variant of Cucumber green mottle mosaic virus in Israel. Phytoparasitica 18: $50-56$

Antignus, Y., Wang, Y., Pearlsman, M., Lachman, O., Lavi, N., and Gal-On, A 2001. Biological and molecular characterization of a new cucurbit-infecting tobamovirus. Phytopathology 91:565-571.

Ataga, A. E., Epton, H. A. S., and Frost, R. R. 1999. Interaction of virus-infected celery and Septoria apiicola. Plant Pathol. 48:620-626.

Ayo-John, E. I., Olorunmaiye, P. M., Odedara, O. O., Olusayo, B. D., Abiola K. O., and Oladokun, J. O. 2014. Assessment of field-grown cucurbit crops and weeds within farms in south-west Nigeria for viral diseases. Not. Sci. Biol. 6:321-325.

Bateman, D. F. 1961. Synergism between Cucumber mosaic virus and Rhizoctonia in relation to Rhizoctonia damping-off of cucumber. Phytopathology 51: 574-575.

Ben-Yephet, Y., and Nelson, E. B. 1999. Differential suppression of damping-off caused by Pythium aphanidermatum, P. irregulare, and P. myriotylum in composts at different temperatures. Plant Dis. 83:356-360.

Beute, M. K., and Lockwood, J. L. 1968. Mechanism of increased root rot in virusinfected peas. Phytopathology 58:1643-1651.

Broadbent, L. 1965. The epidemiology of tomato mosaic. Ann. Appl. Biol. 56: 177-205.

Broadbent, L. 1976. Epidemiology and control of Tomato mosaic virus. Annu. Rev. Phytopathol. 14:75-96.

Cherif, M., Menzies, J. G., Ehret, D. L., Bogdanoff, C., and Belanger, R. R. 1994 Yield of cucumber infected with Pythium aphanidermatum when grown with soluble silicon. HortScience 29:896-897.

Clark, M. F., and Adams, A. N. 1977. Characteristics of the microplate method of enzyme-linked immunosorbent assay for the detection of plant viruses. J. Gen. Virol. 34:475-483.

Dombrovsky, A., Tran-Nguyen, L. T. T., and Jones, R. A. C. 2017. Cucumber green mottle mosaic virus: Rapidly increasing global distribution, etiology, epidemiology, and management. Annu. Rev. Phytopathol. 55:231-256.

Dornai, D., Mingelgrin, U., Frenkel, H., and Bar-Joseph, M. 1993. Direct quantification of unadsorbed viruses in suspensions of adsorbing colloids with the enzyme-linked-immunosorbent-assay. Appl. Environ. Microbiol. 59: 3123-3125.

FAO. 2014. Food and Agriculture Organization of the United Nations. www.fao org (Accessed 15 June 2017).

Fillmer, K., Adkins, S., Pongam, P., and D'Elia, T. 2015. Complete genome sequence of a Tomato mottle mosaic virus isolate from the United States. Genome Announc. 3:e00167-15.

Fletcher, J. T., George, A. J., and Green, D. E. 1969. Cucumber green mottle mosaic virus, its effect on yield and its control in the Lea Valley, England. Plant Pathol. 18:16-22.

Gibbs, A. J., Wood, J., Garcia-Arenal, F., Ohshima, K., and Armstrong, J. S. 2015 Tobamoviruses have probably co-diverged with their eudicotyledonous hosts for at least 110 million years. Virus Evol. 1:vev019.

Glazebrook, J. 2001. Genes controlling expression of defense responses in Arabidopsis-2001 status. Curr. Opin. Plant Biol. 4:301-308.

Hendrix, F. F., and Campbell, W. A. 1973. Pythiums as plant pathogens. Annu. Rev. Phytopathol. 11:77-98.

Herrero, M. L., Hermansen, A., and Elen, O. N. 2003. Occurrence of Pythium spp and Phytophthora spp. in Norwegian greenhouses and their pathogenicity on cucumber seedlings. J. Phytopathol. 151:36-41.

Hollings, M., Komuro, Y., and Tochihara, H. 1975. Cucumber green mottle mosaic virus. Online publication. Descriptions of Plant Viruses 4. http:// www.dpvweb.net/dpv/showdpv.php?dpvno=154 
Ishibashi, K., and Ishikawa, M. 2016. Replication of tobamovirus RNA. Annu. Rev. Phytopathol. 54:55-78.

Ito, M., Meguro-Maoka, A., Maoka, T., Akino, S., and Masuta, C. 2017. Increased susceptibility of potato to Rhizoctonia diseases in Potato leafroll virus-infected plants. J. Gen. Plant Pathol. 83:169-172.

Jaiswal, A. K., Elad, Y., Graber, E. R., and Frenkel, O. 2014. Rhizoctonia solani suppression and plant growth promotion in cucumber as affected by biochar pyrolysis temperature, feedstock and concentration. Soil Biol. Biochem. 69:110-118.

Katan, J. 2010. Cultural approaches for disease management: Present status and future prospects. J. Plant Pathol. 92:S4.7-S4.9.

Koike, H., and Yang, S. 1971. Influence of Sugarcane mosaic virus strain H and Pythium graminicola on growth of sugarcane. Phytopathology 61:1090-1092.

Kosman, E., and Cohen, Y. 1996. Procedures for calculating and differentiating synergism and antagonism in action of fungicide mixtures. Phytopathology 86:1263-1272.

Lakshman, D., Vieira, P., Pandey, R., Slovin, J., and Kamo, K. 2017. Symptom development in response to combined infection of in vitro-grown Lilium longiflorum with Pratylenchus penetrans and soilborne fungi collected from diseased roots of field-grown lilies. Plant Dis. 101:882-889.

Lamichhane, J. R., Dürr, C., Schwanck, A. A., Robin, M. H., Sarthou, J. P., Cellier, V., Messéan, A., and Aubertot, J. N. 2017. Integrated management of dampingoff diseases. A review. Agron. Sustain. Dev. 37:10.

Lamichhane, J. R., and Venturi, V. 2015. Synergisms between microbial pathogens in plant disease complexes: A growing trend. Front. Plant Sci. 6:385.

Le May, C., Potage, G., Andrivon, D., Tivoli, B., and Outreman, Y. 2009. Plant disease complex: Antagonism and synergism between pathogens of the Ascochyta blight complex on pea. J. Phytopathol. 157:715-721.

LéVesque, C. A., and De Cock, A. W. A. M. 2004. Molecular phylogeny and taxonomy of the genus Pythium. Mycol. Res. 108:1363-1383.

Levy, Y., Benderly, M., Cohen, Y., Gisi, U., and Bassand, D. 1986. The joint action of fungicides in mixtures: Comparison of two methods for synergy calculation. EPPO Bull. 16:651-657.

Lievens, B., Claes, L., Vakalounakis, D. J., Vanachter, A. C. R. C., and Thomma, B. P. H. J. 2007. A robust identification and detection assay to discriminate the cucumber pathogens Fusarium oxysporum f. sp. cucumerinum and f. sp. radicis-cucumerinum. Environ. Microbiol. 9:2145-2161.

Ling, K. S., Li, R., and Zhang, W. 2014. First report of Cucumber green mottle mosaic virus infecting greenhouse cucumber in Canada. Plant Dis. 98:701.

Luria, N., Smith, E., Reingold, V., Bekelman, I., Lapidot, M., Levin, I., Elad, N., Tam, Y., Sela, N., Abu-Ras, A., and Ezra, N. 2017. A new Israeli Tobamovirus isolate infects tomato plants harboring Tm-22 resistance genes. PLoS One 12:e170429.

Martin, F. N., and Loper, J. E. 1999. Soilborne plant diseases caused by Pythium spp.: Ecology, epidemiology, and prospects for biological control. Crit. Rev. Plant Sci. 18:111-181

McCullagh, M., Utkhede, R., Menzies, J. G., Punja, Z. K., and Paulitz, T. C. 1996. Evaluation of plant growth-promoting rhizobacteria for biological control of Pythium root rot of cucumbers grown in rockwool and effects on yield. Eur. J. Plant Pathol. 102:747-755.

Murphy, J. F., and Bowen, K. L. 2006. Synergistic disease in pepper caused by the mixed infection of Cucumber mosaic virus and Pepper mottle virus. Phytopathology 96:240-247.

Nash, S. M., and Snyder, W. C. 1962. Quantitative estimations by plate counts of propagules of the bean root rot Fusarium in field soils. Phytopathology 52:567-572.
Nitzany, F. E. 1966. Synergism between Pythium ultimum and Cucumber mosaic virus. Phytopathology 56:1386-1389.

Postma, J., Willemsen-de Klein, M. J., and Van Elsas, J. D. 2000. Effect of the indigenous microflora on the development of root and crown rot caused by Pythium aphanidermatum in cucumber crown on rockwool. Phytopathology 90:125-133.

Reingold, V., Lachman, O., Belausov, E., Koren, A., Mor, N., and Dombrovsky, A. 2016. Epidemiological study of Cucumber green mottle mosaic virus in greenhouses enables reduction of disease damage in cucurbit production. Ann. Appl. Biol. 168:29-40.

Reingold, V., Lachman, O., Blaosov, E., and Dombrovsky, A. 2015. Seed disinfection treatments do not sufficiently eliminate the infectivity of Cucumber green mottle mosaic virus (CGMMV) on cucurbit seeds. Plant Pathol. 64:245-255.

Rose, S., Parker, M., and Punja, Z. K. 2003. Efficacy of biological and chemical treatments for control of Fusarium root and stem rot on greenhouse cucumber. Plant Dis. 87:1462-1470.

Rubio, L., Soong, J., Kao, J., and Falk, B. W. 1999. Geographic distribution and molecular variation of isolates of three whitefly-borne closteroviruses of cucurbits: Lettuce infectious yellows virus, Cucurbit yellow stunting disorder virus, and Beet pseudo-yellows virus. Phytopathology 89:707-711.

Salem, N., Mansour, A., Ciuffo, M., Falk, B., and Turina, M. 2016. A new tobamovirus infecting tomato crops in Jordan. Arch. Virol. 161:503-506.

Shargil, D., Smith, E., Lachman, O., Reingold, V., Darzi, E., Tam, Y., and Dombrovsky, A. 2016. New weed hosts for Cucumber green mottle mosaic virus in wild Mediterranean vegetation. Eur. J. Plant Pathol. 148:473-480.

Sundheim, L., Brurberg, M., Hofsvang, T., Magnusson, C., Rafoss, T., Toppe, B. Tronsmo, A., and Økland, B. 2008. Pest Risk Assessment of the Cucumber green mottle mosaic virus in Norway. Norwegian Scientific Committee for Food Safety, Oslo, Norway.

Tesoriero, L. A., Chambers, G., Srivastava, M., Smith, S., Conde, B., and TranNguyen, L. T. T. 2015. First report of Cucumber green mottle mosaic virus in Australia. Australas. Plant Dis. Notes 11:1.

Tian, T., Posis, K., Maroon-Lango, C. J., Mavrodieva, V., Haymes, S., Pitman, T. L. and Falk, B. W. 2014. First report of Cucumber green mottle mosaic virus on melon in the United States. Plant Dis. 98:1163.

Tollenaere, C., Lacombe, S., Wonni, I., Barro, M., Ndougonna, C., Gnacko, F., Sérémé, D., Jacobs, J. M., Hebrard, E., Cunnac, S., and Brugidou, C. 2017. Virus-bacteria rice co-infection in Africa: Field estimation, reciprocal effects, molecular mechanisms, and evolutionary implications. Front. Plant Sci. 8:645

Tu, J. C., and Ford, R. E. 1971. Maize dwarf mosaic virus predisposes corn to root rot infection. Phytopathology 61:800-803.

Van der Plaats-Niterink, A. J. 1981. Monograph of the Genus Pythium. Studies in Mycology, Vol. 21. Centraalbureau voor Schimmelcultures, Baarn, The Netherlands.

Vos, I. A., Pieterse, C. M. J., and Wees, S. C. M. 2013. Costs and benefits of hormone-regulated plant defences. Plant Pathol. 62:43-55.

White, T. J., Bruns, T., Lee, S., and Taylor, J. W. 1990. Amplification and direct sequencing of fungal ribosomal RNA genes for phylogenetics. Pages 315-322 in: PCR Protocols: A Guide to Methods and Applications. M. A. Innis, D. H. Gelfand, and J. J. Sninsky, eds. Academic Press, New York.

Zitter, T. A., Hopkins, D. L., and Thomas, C. E. 1996. Compendium of Cucurbits Diseases. American Phytopathological Society, St. Paul, MN. 